\title{
6: 69404158-7056120
}

National Cancer Institute

\section{Source}

National Cancer Institute. 6:69404158-7056120. NCI Thesaurus. Code C41744.

Physical location of BAI3_Gene 